\title{
Zelfafnametest baarmoederhalskanker betrouwbaar
}

Femke Smits, Michiel Bos

Sinds 2017 is het Nederlandse bevolkingsonderzoek baar-
moederhalskanker aangepast. Zo is het voor vrouwen die
niet voor een uitstrijkje naar de huisartsenpraktijk willen
komen nu mogelijk om een zelfafnametest aan te vragen. De
zelfafnametest lijkt even betrouwbaar als een uitstrijkje voor
screening op hrHPV, blijkt uit recent Nederlands onderzoek.

Niet alle vrouwen komen naar de praktijk om een uitstrijkje te laten maken. Wij vroegen ons af of de zelfafnametest voor deze vrouwen een betrouwbaar alternatief is.

We zochten op 6 maart 2018 in PubMed met de zoektermen: 'Human papillomavirus 16' [Mesh] OR 'human papillomavirus'[tiab]) AND ('Diagnostic Self Evaluation'[Mesh] OR self $\operatorname{diagnos}^{\star}$ [tiab] OR self sampl ${ }^{\star}[$ tiab]) AND ('Vaginal Smears' [Mesh] OR vaginal smear ${ }^{\star}\left[\right.$ tiab] OR cervical smear ${ }^{\star}$ [tiab] OR PAP smear* [tiab] OR physician taken smear) AND (population based screening OR preventive medicine OR prevent $^{\star}$ [tiab] OR responder population). Dit leverde 43 resultaten op. We maakten een verdere selectie op basis van titel en abstract. Twee onderzoeken waren relevant voor het beantwoorden van de onderzoeksvraag. ${ }^{1,2}$

\section{ZELFAFNAMETEST NA REGULIER UITSTRIJKJE}

Ketelaars et al. includeerden in het VERA-onderzoek 2460 vrouwen die zichzelf meldden voor het Nederlands bevolkingsonderzoek baarmoederhalskanker. Nadat er in de huisartsenpraktijk een regulier uitstrijkje was afgenomen, werd de vrouw geïnstrueerd een zelfafnametest uit te voeren met een Evalyn Brush. Uitstrijkje en zelfafnametest werden getest op 14 hrHPV-genotypes. Uiteindelijk hebben de onderzoekers van 2049 vrouwen zowel de uitstrijkjes als de zelfafnametests geanalyseerd. Van 316 vrouwen ontvingen zij niet beide samples. Verder konden 28 samples niet worden getest door ontbreken van B-globuline, en konden 20 uitstrijkjes en 47 zelfafnametests niet worden getest door te veel bijmenging van bloed of slijm. Uitstrijkje en zelftest bleken bij 96,8\% (95\%-BI $96,0$ tot 97,5$)$ van de vrouwen tot hetzelfde testresultaat te leiden. Bij 12 vrouwen $(0,6 \%)$ was de zelfafnametest negatief en de hrHPV-test op het uitstrijkje positief; deze vrouwen zouden dus niet nader zijn onderzocht als ze alleen een zelfafnametest hadden gedaan. Omgekeerd was bij 53 vrouwen $(2,6 \%)$ het uitstrijkje negatief en de zelfafnametest positief. Dit brengt ons meteen bij een belangrijke beperking van dit onderzoek. De testuitslagen zijn niet afgezet tegen de gouden standaard (colposcopie met biopsie), waardoor we niet weten welke tests terecht positief of terecht negatief waren. Bovendien is het denkbaar dat de testvolgorde, uitstrijkje gevolgd door zelfafnametest, invloed kan hebben op de resultaten van de zelfafnametests.

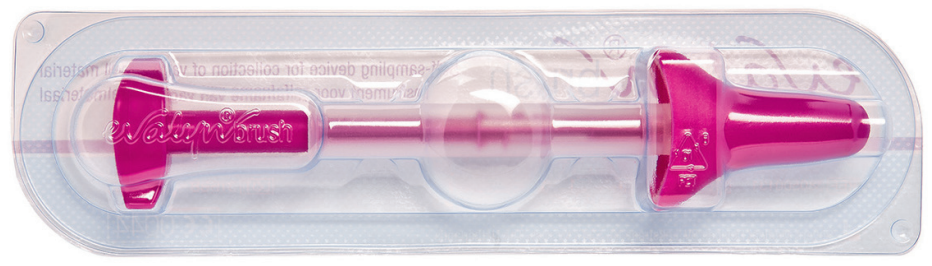

Het is nog te vroeg zelfafnametests voor baarmoederhalskanker als primaire screeningstool in te zetten.

Het VERA-onderzoek van Ketelaars sluit aan bij een eerder gepubliceerde meta-analyse met 154.556 deelnemers. ${ }^{2}$ Uit het geaggregeerde resultaat van alle onderzoeken in deze meta-analyse bleek dat een door een arts afgenomen test betrouwbaarder is dan een zelftest. In een subanalyse van onderzoeken waarin de aanwezigheid van hrHPV werd bepaald met een moderne PCR-test, zoals ook Ketelaars en het Nederlands bevolkingsonderzoek gebruiken, werd echter geen verschil gezien in relatieve sensitiviteit en specificiteit tussen beide testvormen. Binnen het VERA-onderzoek vond 98,5\% van de vrouwen de zelfafnametest gebruiksvriendelijk en $62,8 \%$ verkiest de zelfafnametest boven het uitstrijkje.

\section{TOEPASBAARHEID IN DE PRAKTIJK}

We concluderen dat we individuele vrouwen met een gerust hart een zelfafnametest kunnen laten uitvoeren om te screenen op hrHPV, omdat deze test even betrouwbaar is. Het is echter nog te vroeg de zelfafnametests als primaire screeningstool voor alle deelneemsters aan het bevolkingsonderzoek in te zetten. Daarvoor dient eerst duidelijk te zijn of de zelftest leidt tot een betere deelname en dient de zelftest vergeleken te worden met de gouden standaard, de colposcopie.

\section{LITERATUUR}

1. Ketelaars PJW, Bosgraaf RP, Siebers AG, Massuger LFAG, Van der Linden JC, Wauters CAP, et al. High-risk human papillomavirus detection in self-sampling compared to physician-taken smear in a responder population of the Dutch cervical screening. Results of the VERA study. Preventive Medicine 2017;101:96-101.

2. Arbyn M, Verdoodt F, Snijders PJ, Verhoef VM, Suonio E, Dillner L, et al. Accuracy of human papillomavirus testing on self-collected versus clinician-collected samples: a meta-analysis. Lancet Oncology 2014;15:172-83.

Smits F, Bos M. Zelfafnametest baarmoederhalskanker betrouwbaar. Huisarts Wet 2018;61[7]:67. DOI: 10.1007/s12445-018-192-2.

Erasmus MC, afdeling Huisartsgeneeskunde, Rotterdam: F.M.F. Smits, huisarts-in-opleiding; dr. M.J. Bos, huisarts-epidemioloog, docent wetenschap, correspondentie: m.j.bos.1@erasmusmc.nl.

Mogelijke belangenverstrengeling: niets aangegeven.

Dit is een CAT, critically appraised topic, waarbij de auteur een evidence-based antwoord op een praktijkvraag wil krijgen. 